\title{
Discrimination of Athletes and Non-athletes Based on the Latent Structure of Some Biometric Variables
}

\author{
Discriminación entre Atletas y No Atletas Basada \\ en la Estructura Latente de Algunas Variables Biométricas
}

Agron M. Rexhepi ${ }^{*, * * * * * * *}$ \& Behlul Brestovci ${ }^{* * *, * * * * *}$

REXHEPI, A. M. \& BRESTOVCI, B. Discrimination of athletes and non-athletes based on the latent structure of some biometric variables. Int. J. Morphol., 31(3):957-962, 2013.

SUMMARY: The aim of this exploratory study was to explore impact of organized physical activities on the latent structure of some morpho-functional variables. Discrimination between group of athletes (167 entities, aged 22.4 years) and group of non-athletes (150 entities, aged 25.7 years) has been explored in latent structure of 12 morphometric variables, 4 physiological variables and 7 hematological variables. The significant differences between athletes and non-athletes on four extracted latent factors, were explored through Canonical Discriminant Analyses. The confirmed significant differences between two explored groups indicate the impact of regular and well organized physical activities on morphometric characteristics, physiological abilities, and hematological parameters. The results of this exploratory study may encourage us to compose and to apply well organized physical activities for children, elders, and overweight persons that will be profitable for their health.

KEY WORDS: Canonical discriminant analyses; Latent factors; Morpho-functional variables.

\section{INTRODUCTION}

There are number of studies dealing with regularly sport training as well as with sport nutrition as two very important external factors, which together with genetic factor, significantly affect on morpho-functional performances of athletes (McArdle et al., 2001). The measurement of the basic morpho-functional characteristics of the athletes are the foundation on which may be evaluated the efficiency of the training process on developing of these abilities. It is known that endurance and resistance exercises increase the amount of human growth hormone in circulation (Godfrey et al., 2003; Jenkins, 1999; Sutton \& Lazarus, 1976).

Many researches show that the athletes can show big potential and maintain their high performance, only if their cardio respiratory function, energy expenditure, and blood lactate system are well controlled (Imamura et al., 1999). The elite athletes have lower heart rate at rest, before and after exercise, as well as they can recover quickly to a rest state, compared with non-athletes (Jack \& David, 1999).
Enhancement of morpho-functional abilities of athletes such as aerobic and anaerobic capacity, speed, muscle strength, recovery and neuromuscular coordination, are the main duties of sport science training. Ability of an athlete to perform at peak performance during the main competition is also related to strength training (Zabukovec \& Tiidus, 1995). According to many scientists (Bangsbo et al., 2006; Howley et al., 1995; Hoff et al., 2002; Midgley et al., 2007) the physical conditioning, respectively, aerobic capacity depend upon: maximal oxygen consumption, anaerobic threshold, work economy and recovery to maintain good performance throughout the competitive phase the gained physiological base, respectively skills, of the athletes must be maintained (Bompa \& Carrera, 2005).

The determination of physiological variables, such as the anaerobic threshold and maximal oxygen uptake, will help in realization of the major requirement for coaches and athletes: to define the endurance performances of athletes (Bentley et al., 2001).

\footnotetext{
" Centre for Sport, Fitness and Nutrition "Corpore Sano", Prishtina, Kosova.

** University College for Sport and Education "Universi", Bardhosh, Prishtina, Kosova.

**** Institute of Sport Anthropology, Prishtina, Kosova.

*****Faculty of Special Education and Rehabilitation, University of Zagreb, Zagreb, Croatia.
} 
Prolonged bouts of strenuous exercise may cause a temporary depression of various aspects of immune function that usually lasts approximately 3-24 hours after exercises, depending on the intensity and duration of the exercise bout. This post-exercise immune function depression, respectively the higher susceptibility to infection in athletes, is most pronounced when exercise is continuous, prolonged, of moderate to high intensity and performed without food intake (Gleeson et al., 2006).

Heavy exercise may also increase iron needs by up to another 1 to 2 milligrams day. This may be caused by a combination of factors, including iron loss in sweat, blood loss from the urinary tract or gastrointestinal system and the breakdown of the red blood cells in the circulation from heavy foot striking (foot-strike hemolysis). Approximately, $25 \%$ of female and $10 \%$ of male athletes have iron deficiency (Constantini et al., 2000; Dubnov \& Constantini, 2004). Even if, athletes are more sensitive to the effects of iron deficiency because they depend on the body's ability to transport oxygen to the muscles, among them, the prevalence of iron depletion without anemia seems to be significantly higher than among the general population (Constantini et al.).

The clinical signs of iron deficiency anemia are wellknown: a decrease in physical and mental performance.

The aim of this exploratory study was to explore impact of organized physical activities on the latent structure of some morpho-functional variables of the people who trained systematically.

\section{MATERIAL AND METHOD}

This research is a part of the project: "The differences between athletes and non-athletes of Kosova", realized in Center for Sports Medicine and Recreation in Prishtina, Kosova.

Differences between group of athletes (167 entities, aged 22.4 years) and group of non-athletes (150 entities, aged 25.7 years) has been explored in latent structure of 12 morphometrical variables, 4 physiological variables and 7 hematological variables. The tested athletes were professional footballers and basketballers from Kosova.

Trying to avoid mistakes during measurements, the sports entities were measured in the morning hours (08:00 11:00 Am).

The measurement procedures were done in the Center of Sports Medicine and Recreation in Prishtina - Kosovo, during the period $2002-2003$, and were in accordance with the ethical standards of the Ethics Committee of University Clinical Center in Prishtina.

The following 12 morphometrical variables were measured according to the standards and instructions of the International Biological Program, using the classic anthropometrical instruments (anthropometer, classic weigher, millimetric tape, and skinfold caliper):

Stature - Body height measures the distance from the standing surface to the top (vertex) of the skull.

Body volume and weight variables:

- Body Weight - Is a measure of body mass;

- Humeral Perimeter - shows maximum circumference of the arm (humerus);

- Chest Perimeter - shows maximum circumference of the thorax at the mammilla level;

- Abdominal Perimeter - shows circumference of the abdomen at the umbilicus level;

- Thigh Perimeter - shows maximum circumference of the thigh;

- Calf Perimeter - shows maximum circumference of the calf;

- Skinfold thickness variables:

- Triceps Skinfold - shows subcutaneous adipose tissue on the back of the arm (humerus) over the triceps muscle;

- Subscapular Skinfold - shows subcutaneous adipose tissue on the back just below the inferior angle of scapula;

- Abdominal Skinfold - shows subcutaneous adipose tissue of the abdomen at the umbilicus level $5 \mathrm{~cm}$ on the left;

- Thigh Skinfold - shows subcutaneous adipose tissue on the thigh;

- Calf Skinfold - shows subcutaneous adipose tissue on the calf, measured at the same level like calf's perimeter;

Physiological variables:

- Heart Rate - is determined by the number of heartbeats per unit of time (expressed as beats per minute - BPM). Heart rate was measured by stethoscope on apex cordis.

- Systolic blood pressure - Is a measure of blood pressure while the heart is beating (has been measured with sphygmomanometer).

- Diastolic pressure - Is a measure of blood pressure while the heart is relaxed (has been measured with sphygmomanometer).

- $\mathrm{VO}_{2} \max$ - refers to the maximum amount of oxygen that an individual can utilize during intense or maximal exercise. It is measured as "milliliters of oxygen used in one minute per kilogram of body weight." 
Hematological variables:

- Erythrocytes - or red blood cells, make up the largest population of blood cells, numbering from 4.5 million to 6 million per $\mathrm{mm}^{3}$ of blood.

- Hemoglobin - is the essential protein that carries oxygen in the red blood cell. The hemoglobin test measures the grams of hemoglobin per 100 milliliters of blood volume. Normal values for women are 12 to $15 \mathrm{~g} / 100 \mathrm{ml}$ of blood.

- Leucocytes - or white blood cells are cells of the immune system involved in defending the body against both infectious disease and foreign materials.

- Hematocrit - The hematocrit test measures the percentage of plasma that red blood cells comprise.

- Glycemia - means the level of glucose in one's blood.

- Urea-is an organic chemical compound which essentially is the waste produced when the body metabolizes protein.

- Creatine - is naturally produced in the human body from amino acids primarily in the kidney and liver. It is transported in the blood for use by muscles.

The gained results, initially, were analyzed in terms of basic statistical parameters. Through Factor Analysis has been analyzed the latent structure of measured variables. And, finally the differences between athletes and non-athletes on the level of the extracted latent factors were explored through applied the statistical procedures of T-test, and Canonical Discriminant Analysis.

Table I. Descriptive Statistical Parameters.

\begin{tabular}{lcccc}
\hline Variables & \multicolumn{2}{c}{ Athletes $(\mathbf{n}=\mathbf{1 6 7})$} & \multicolumn{2}{c}{ Non-Athletes $(\mathbf{n}=\mathbf{1 5 0})$} \\
\cline { 2 - 5 } & Mean & SD & Mean & SD \\
\hline Body Weight & 71.13 & 9.55 & 72.31 & 9.33 \\
Stature & 1771.52 & 73.94 & 1759.83 & 51.09 \\
Humeral Perimeter & 275.95 & 26.65 & 286.60 & 26.32 \\
Chest Perimeter & 905.34 & 50.84 & 939.27 & 63.45 \\
Abdominal Perimeter & 776.41 & 59.67 & 810.12 & 82.31 \\
Thigh Perimeter & 545.71 & 41.83 & 545.41 & 46.55 \\
Calf Perimeter & 366.52 & 24.81 & 361.56 & 26.82 \\
Triceps Scinfold & 79.03 & 36.37 & 91.95 & 47.11 \\
Subscapular Scinfold & 86.80 & 33.89 & 105.39 & 46.66 \\
Abdominal Scinfold & 95.56 & 58.37 & 146.10 & 91.30 \\
Thigh Scinfold & 109.28 & 70.24 & 156.62 & 95.79 \\
Calf Scinfold & 82.49 & 40.68 & 91.19 & 46.78 \\
Heart Rate 0 & 66.87 & 11.30 & 75.99 & 12.56 \\
Systolic Pressure & 112.40 & 11.37 & 112.42 & 12.21 \\
Diastolic Pressure & 76.30 & 7.25 & 76.05 & 8.53 \\
VO ${ }_{2}$ max.abs & 3.20 & 0.27 & 2.73 & 0.28 \\
Erythrocytes & 4.16 & 0.24 & 4.09 & 0.22 \\
Hemoglobin & 138.96 & 11.83 & 135.08 & 10.51 \\
Leucocytes & 6.38 & 1.36 & 6.10 & 1.36 \\
Hematocrit & 44.89 & 3.28 & 45.77 & 3.23 \\
Glycemia & 4.75 & 1.51 & 4.41 & 0.66 \\
Urea & 5.79 & 1.35 & 5.29 & 1.30 \\
Creatine & 73.29 & 10.76 & 77.58 & 7.71 \\
\hline
\end{tabular}

\section{RESULTS AND DISCUSION}

All statistical procedure was based on the statistical package SPSS 17 for Windows. The findings of descriptive statistical parameters, for the measured variables in each treated group, are shown in Table I. According to results of Table I we can conclude the systematic differences on almost all measured variables between group of athletes and group of non-athletes.

Factor analysis is used to study the patterns of relationship among many dependent variables, with the goal of discovering latent variables which affect them. These independent variables could not be measured directly.

The appropriateness of factor analysis is tested by Kaiser-Meyer-Olkin (KMO) index, and Bartlett's Test of Sphericity.

Based on the high value of KMO index (0.856) and significance of Bartlet's Test of Sphericity (Sig. $=0.000)$ shown on Table II, we can conclude that the relationships among measured variables are very strong - so we can continue with further procedures of factor analysis.

According to principal component analysis of Factor Analysis, with rotation method direct oblimin, and using SMC criterion (minimal common variability), have been extracted four latent components (factors) that explains 59.43\% of total variance (Table II).

Once the optimal number of factors has been determined, we should try to interpret the meaning of these factors. The oblique rotation solutions are more interpretable than the orthogonal rotation solutions. And because the pattern matrix (Table III) allows the easiest interpretation of extracted latent factors, as well contains coefficients which represent unique contributions, we'll try to explain the results of this matrix.

Based on Table III we can conclude that the best projections on the first extracted latent factor have realized all the anthropometric variables that provide information about body weight, volume and skinfold. So, this factor, which explains $34.88 \%$ of total variance, might be appointed as factor of body weight, volume and skinfold. 
Table II. Total Variance Explained, Communality, Coefficient of multiple correlations, SMC criterion.

\begin{tabular}{|c|c|c|c|c|c|c|}
\hline Component & Total & \% of Variance & Cumulative \% & $\mathbf{h}^{2}$ & $\mathbf{R}^{2}$ & $\begin{array}{c}\text { SMC- } \\
\text { criterion }\end{array}$ \\
\hline 1 & 8.02 & 34.88 & 34.88 & 0.96 & 0.95 & \\
\hline 2 & 2.28 & 9.91 & 44.78 & 0.71 & 0.68 & \\
\hline 3 & 1.95 & 8.48 & 53.26 & 0.75 & 0.75 & \\
\hline 4 & 1.42 & 6.17 & 59.43 & 0.79 & 0.78 & \\
\hline 5 & 1.37 & 5.97 & 65.39 & 0.82 & 0.85 & \\
\hline 6 & 1.15 & 5.00 & 70.39 & 0.85 & 0.86 & \\
\hline 7 & 1.09 & 4.75 & 75.15 & 0.71 & 0.68 & \\
\hline 8 & 0.93 & 4.04 & 79.19 & 0.78 & 0.72 & \\
\hline 9 & 0.86 & 3.73 & 82.92 & 0.82 & 0.82 & \\
\hline 10 & 0.74 & 3.20 & 86.12 & 0.82 & 0.82 & \\
\hline 11 & 0.57 & 2.49 & 88.61 & 0.87 & 0.84 & \\
\hline 12 & 0.56 & 2.43 & 91.04 & 0.75 & 0.76 & \\
\hline 13 & 0.39 & 1.70 & 92.74 & 0.76 & 0.41 & \\
\hline 14 & 0.34 & 1.47 & 94.21 & 0.79 & 0.42 & \\
\hline 15 & 0.26 & 1.11 & 95.32 & 0.78 & 0.43 & \\
\hline 16 & 0.24 & 1.02 & 96.34 & 0.81 & 0.50 & \\
\hline 17 & 0.22 & 0.93 & 97.27 & 0.90 & 0.88 & \\
\hline 18 & 0.16 & 0.71 & 97.99 & 0.90 & 0.88 & \\
\hline 19 & 0.14 & 0.59 & 98.57 & 0.33 & 0.07 & \\
\hline 20 & 0.12 & 0.51 & 99.08 & 0.52 & 0.20 & \\
\hline 21 & 0.11 & 0.48 & 99.56 & 0.42 & 0.07 & \\
\hline 22 & 0.06 & 0.27 & 99.82 & 0.72 & 0.21 & \\
\hline 23 & 0.04 & 0.18 & 100.00 & 0.71 & 0.25 & 0.60 \\
\hline
\end{tabular}

Table III. Pattern Matrix.

\begin{tabular}{|c|c|c|c|c|}
\hline Variables & Factor 1 & Factor 2 & Factor 3 & Factor 4 \\
\hline Body Weight & $* 0.90$ & 0.01 & 0.27 & 0.16 \\
\hline Stature & 0.23 & 0.12 & $* 0.42$ & 0.39 \\
\hline Humeral Perimeter & $* 0.84$ & -0.02 & 0.01 & 0.03 \\
\hline Chest Perimeter & $* 0.80$ & -0.02 & 0.06 & 0.08 \\
\hline Abdominal Perimeter & $*_{0.88}$ & 0.04 & -0.03 & 0.02 \\
\hline Thigh Perimeter & $* 0.90$ & -0.06 & 0.21 & 0.09 \\
\hline Calf Perimeter & $*_{0.75}$ & -0.09 & 0.37 & 0.08 \\
\hline Triceps Scinfold & $* 0.77$ & 0.11 & -0.23 & 0.00 \\
\hline Subscapular Scinfold & $*_{0.83}$ & 0.06 & -0.25 & -0.13 \\
\hline Abdominal Scinfold & $* 0.82$ & 0.00 & -0.32 & -0.08 \\
\hline Thigh Scinfold & $* 0.81$ & 0.01 & -0.33 & -0.05 \\
\hline Calf Scinfold & $* 0.72$ & 0.03 & -0.17 & 0.00 \\
\hline Heart Rate 0' & 0.23 & 0.06 & $*_{-0.59}$ & 0.16 \\
\hline Systolic Pressure & 0.47 & -0.03 & 0.15 & $*_{-0.48}$ \\
\hline Diastolic Pressure & 0.46 & -0.04 & 0.14 & $*_{-0.58}$ \\
\hline $\mathrm{VO}_{2} \max . \mathrm{abs}$ & -0.09 & 0.07 & $* 0.81$ & 0.05 \\
\hline Erythroc ytes & 0.04 & $* 0.93$ & 0.04 & 0.04 \\
\hline Hemoglobin & -0.03 & $* 0.93$ & 0.06 & 0.02 \\
\hline Leucocytes & -0.04 & $* 0.26$ & 0.08 & -0.21 \\
\hline Hematocrit & 0.06 & $* 0.54$ & -0.13 & 0.12 \\
\hline Glycemia & 0.04 & 0.08 & 0.00 & $* 0.27$ \\
\hline Urea & 0.05 & 0.00 & 0.18 & $* 0.56$ \\
\hline Creatine & 0.12 & -0.32 & -0.06 & $* 0.51$ \\
\hline
\end{tabular}

On the second factor, which explains $9.91 \%$ of total variance, the best projections have realized four hematologic variables that provide us with information of hematogram. Two of these variables, which inform about red blood cells (erythrocytes 0.93, hemoglobin 0.93), realized the higher values of projections on this factor. Rightly, this factor might be known as the hematopoietic factor.

On third latent factor that explains $8.48 \%$ of total variance, the best projections have realized one anthropometric variable (Stature), together with heart rate (HR), as well maximal oxygen uptake $\left(\mathrm{VO}_{2} \max \right)$. This factor we might appoint as factor of stature and the aerobic ability.

On fourth extracted factor, which explains $6.17 \%$ of total variance, the best projections have realized the variables of blood pressure, blood sugar, urea, and creatine.

The results shown on Table IV, shows that the four extracted latent factors have not realized significant correlation between them, so they can stay independently.

One-dimensional differences of latent space, between group of nonathletes and group of athletes, have been explored using t-test. According to the results of Table $\mathrm{V}$ we can conclude the significant differences between nonathletes and athletes in first, second and third latent factor, whereas in fourth latent factor they are similar. Among three latent factors that have significant discriminant power, third factor, which informs us about stature and conditioning abilities of tested entities, has the higher impact in discrimination between groups.

As has been mentioned, the aim of this exploratory study was to determine the significant differences in latent structure between group of non-athletes 
Table IV. Component Correlation Matrix.

\begin{tabular}{lcccc}
\hline Components & Factor 1 & Factor 2 & Factor 3 & Factor 4 \\
\hline Factor 1 & 1.000 & & & \\
Factor 2 & $1.749 \mathrm{E}-02$ & 1.000 & & \\
Factor 3 & $-4.297 \mathrm{E}-02$ & $3.044 \mathrm{E}-02$ & 1.000 & \\
Factor 4 & $4.622 \mathrm{E}-02$ & $-1.633 \mathrm{E}-02$ & $2.442 \mathrm{E}-02$ & 1.000 \\
\hline
\end{tabular}

Table V. T-test for independent groups.

\begin{tabular}{llll}
\hline Components & $\mathbf{t}$ & df & Sig. \\
\hline Factor 1 & 3.214 & 315 & 0.001 \\
Factor 2 & -2.481 & 315 & 0.014 \\
Factor 3 & -13.153 & 315 & 0.000 \\
Factor 4 & .890 & 315 & 0.374 \\
\hline
\end{tabular}

and the group of athletes. In this purpose, the canonical discriminant analysis was used to determine which of the latent variables better discriminates two tested groups. Because the measurements have been done on two groups, the obtained matrix is singular with one discriminant function (Summary of canonical discriminant functions: Function $1=0.656, \mathrm{Rc}=0.629$, Wilks' Lambda=0.604, Chisquare $=157.864, \mathrm{Sig} .=0.001)$.

Based on this results, we can ascertain the significant differences $(\mathrm{Sig}=0.000)$ between two tested groups on the system of the latent variables. On Table VI are shown the correlations that four latent factors were realized on discriminant function (structure of the canonical discriminant function).

Table VI. Structure Matrix.

\begin{tabular}{ll}
\hline Components & Function \\
\hline Factor 3 & 0.915 \\
Factor 1 & -0.224 \\
Factor 2 & 0.173 \\
Factor 4 & -0.062 \\
\hline
\end{tabular}

Arithmetic mean of the discriminant values of the tested groups, which presents centroid of a group (Non-athletes=-0.852 and Athletes $=0.765$ ), indicates that differences between two tested groups are more than 1.5 Sigma.

According to the structure of discriminant function (Table VI), and values of the group centroids, can be explained the characteristics of groups that were tested: Athletes compared with non-athletes are characterized with higher stature, better aerobic abilities, lower values of adipose tissue, and more or less, better values of blood elements.

\section{CONCLUSIONS}

The results of this exploratory study, confirm influence of regular physical activities on latent structure of morpho-physiological and hematological parameters, as well these results can be applied to few categories of population:

- Children - If parents encourage sports participation at an early age, the child will have a better chance for the healthy morphometrical and physiological development;

- Obese persons - Regular physical activities associated with healthy nutritional diet, significantly will impact on reducing of adipose tissue, as well on decreasing of overweight;

- Elders - Regular physical activities to this category will help them to maintain cardiorespiratory system, as well loco-motor system.

REXHEPI, A. M. \& BRESTOVCI, B. Discriminación entre atletas y no atletas basada en la estructura latente de algunas variables biométricas. Int. J. Morphol., 31(3):957-962, 2013.

RESUMEN: El objetivo de este estudio exploratorio fue determinar el impacto de las actividades físicas organizadas sobre la estructura latente de algunas variables morfo-funcionales. Se estudiaron y discriminaron entre un grupo de atletas (167 sujetos, edad promedio 22,4 años) y no atletas (150 sujetos, edad promedio 25,7 años) la estructura latente de 12 variables morfométricas, 4 variables fisiológicas y 7 variables hematológicas. Las diferencias significativas entre los atletas y no atletas en cuatro factores latentes se estudiaron mediante análisis discriminantes canónicos. Las diferencias significativas entre los dos grupos demuestran el impacto de las actividades físicas regulares y bien organizadas sobre las características morfométricas, capacidades fisiológicas y parámetros hematológicos. Los resultados de este estudio exploratorio pueden incentivarnos a componer y aplicar actividades físicas bien organizadas para niños, ancianos y personas con sobrepeso, las que serán beneficiosas para su salud.

PALABRAS CLAVE: Análisis discriminantes canónicos; Factores latentes; Variables morfofuncionales. 


\section{REFERENCES}

Bangsbo, J.; Mohr, M.; Poulsen, A.; Perez-Gomez, J. \& Krustrup, P. Training and testing the elite athlete. J. Exerc. Sci. Fit., 4(1):114, 2006.

Bentley, D. J.; Mcnaughton, L. R.; Thompson, D. \& Batterham, A. M. Peak power, the lactate threshold, and time trail performance in cyclists. Med. Sci. SportS Exerc., 33(12):2077-81, 2001.

Bompa, T. O. \& Carrera, M. C. Periodization training for sport. Champaign, Human Kinetics, 2005.

Constantini, N. W.; Eliakim, A.; Zigel, L.; Yaaron, M. \& Falk, B. Iron status of highly active adolescents: evidence of depleted iron stores in gymnasts. Int. J. Sport Nutr. Exerc. Metab., 10(1):62-70, 2000.

Dubnov, G. \& Constantini, N. W. Prevalence of iron depletion and anaemia in top level basketball players. Int. J. Nutr. Sport Exerc. Metab., 14(1):30-7, 2004.

Glesson, M.; McFarlin, B. \& Flynn, M. Exercise and Toll-like receptors. Exerc. Immunol. Rev., 12:34-53, 2006.

Godfrey, R. J.; Madgwick, Z. \& Whyte, G. P. The exercise-induced growth hormone response in athletes. Sport Med., 33(8):599$613,2003$.

Hoff, J.; Wisloff, U.; Engen, L. C.; Kemi, O. J. \& Helgerud, J. Soccer specific aerobic endurance training. Br. J. Sports Med., 36(3):218-321, 2002.

Howley, E. T.; Bassett, D. R. Jr. \& Welch, H. G. Criteria for maximal oxygen uptake: review and commentary. Med. Sci. Sports Exerc., 27(9):1292-301, 1995.

Imamura, H.; Yoshimura, Y.; Nishimura, S.; Nakazawa, A. T.; Nishimura, C. \& Shirota, T. Oxygen uptake, heart rate, and blood lactate responses during and following karate training. Med. Sci. Sports Exerc., 31(2):342-7, 1999.

Jack, H. W. \& David, L. C. Physiology of Sport and Exercise. Champaign, Human Kinetics, 1999.

Jenkins, P. J. Growth hormone and exercise. Clin. Endocrinol., 50(6):683-9, 1999.

McArdle, W. D.; Katch, F. I. \& Katch, V. L. Exercise physiology: Energy, nutrition, and human performance. 5th ed. Baltimore, Lippincott Williams \& Wilkins, 2001.

Midgley, A. W.; McNaughton, L. R. \& Carroll, S. Effect of the $\mathrm{VO} 2$ time-averaging interval on the reproducibility of $\mathrm{VO} 2 \mathrm{max}$ in healthy athletic subjects. Clin. Physiol. Funct. Imaging, 27(2):122-5, 2007.
Sutton, J. \& Lazarus, L. Growth hormone in exercise: comparison of physiological and pharmacological stimuli. J. Appl. Physiol., 41(4):523-7, 1976.

Zabukovec, R. \& Tiidus, P. M. Physiological and anthropometrical profile of elite kick boxers. J. Strength Condit. Res., 9(4):2402,1995 .

Correspondence to:

Agron M. Rexhepi

Str. "Sali Butka" Nr. 31/D

Prishtina 10000

KOSOVO

Phone: +377 44110855 ,

Email: agronmrexhepi@gmail.com

Received: 14-03-2013

Accepted: 12-08-2013 